\title{
Addressing Water Issues: Need of the Hour
}

\author{
Ashima Aggarwal
}

\begin{abstract}
The water resources of a nation are invaluable assets which must be preserved and maintained. About $2.7 \%$ of the total water available on the earth is fresh water, of which about $75.2 \%$ lies frozen in polar regions and another $22.6 \%$ is present as ground water. The rest is available in lakes, rivers, atmosphere, moisture, soil and vegetation. Depletion of available freshwater resources, falling ground water levels and deteriorating water quality are all posing a variety of challenges in managing India's water resources. Excessive withdrawal from underground sources affects the chemical quality of water. We had also polluted many of the available water sources, and still continue to pollute them by discharging sewage and industrial waste into rivers.It is estimated that about 38,000 million litres per day (mld) of wastewater are generated in the urban centres having population more than 50,000 in India. Proper planning is, therefore necessary so as to obtain many benefits from it with minimum expenditure.Improving efficiencies and minimizing losses, recharging groundwater aquifers, abatement and treatment of pollution, reuse and recycling of wastewater, due to the complexity and urgency of the environmental challenges, these approaches need to be simultaneously pursued.
\end{abstract}

Keywords: Depletion, Groundwater, Management, Population, Resources

\section{Introduction}

Water is an excellent resource of a nation, as it can be made to serve various functions. Due to ever increase in population of major cities, there is always a great demand for increased water supply. It has put pressure on groundwater, due to which groundwater level is lowering. Over the years, thousands of farmers have lost access to groundwater permanently, due to lowering of water levels to economically inaccessible levels. While the poor farmers do not have resources to invest in deep tube wells, the rich enjoy unlimited access to groundwater at highly subsidized costs owing to heavy electricity subsidies for pumping. But, if not properly harnessed, it can become an enemy in the forms of severe storms, floods and hurricanes. Industry stands second as the largest user of water. The hot water disposed of from steel mills or from thermal stations into rivers, may completely eliminate fish and other forms of aquatic life from rivers. Just like steel industry, there are various other industries such as paper industry, oil industry and detergent industry which require huge quantities of clean water and then dispose of their waste into rivers. The clear fresh waters, that are our national heritage and precious resources, are thus becoming dumping grounds for garbage and filth.

The crisis about water resources development and management arises because most of the water is not available for use and secondly it is characterized by its highly uneven spatial distribution. When management aspect is not properly recognized and due importance is not given to it, the quality of water and functioning of the system deteriorates, the municipal records are not properly maintained and there is loss of revenue. This results in malfunctioning of entire system, the health of the entire community is put in danger and maintenance cost becomes prohibitive.

\section{Water Issues}

There are various issues concerning water resources which include water insecurity, ground water depletion and its contamination, pollution and inadequate wastewater treatment capacity. These issues have been explained below:

\subsection{Population Stress \& Water Insecurity}

Water security is emerging as an important and vital issue for India. Many Indian cities are beginning to experience moderate to severe water shortages, brought on by the simultaneous effects of agricultural growth, industrialization and urbanization. These shortages would be further aggravated by receding of glaciers and dwindling fresh water resources.

India's population is 1,210 million as per 2011 Census. The population of India is expected to stabilize at around 1,640 million by the year 2050 . As a result, gross per capita water availability will decline from $1,820 \mathrm{~m}^{3} / \mathrm{yr}$ in 2001 to as low as $1,140 \mathrm{~m}^{3} / \mathrm{yr}$ in 2050 . Total water requirement of the country for various activities around the year 2050 has been estimated to be $1,450 \mathrm{~km}^{3} / \mathrm{yr}$. This is significantly more than the current estimate of utilizable water resource potential $\left(1,122 \mathrm{~km}^{3} / \mathrm{yr}\right)$ through conventional development strategies. Therefore, when compared with the availability of approximately $500 \mathrm{~km}^{3} / \mathrm{yr}$ at present the water availability around 2050 needs to be almost trebled. Various options have been considered, in quantitative terms, as possible sources to augment the anticipated deficit. It is argued that due to considerations of gestation period and capital requirements, rainwater harvesting and water-conservation measures must receive the highest priority, followed by renovation and recycling to be followed by intra-basin and then inter-basin transfers in the last phase. But, investigations and planning processes for all options must begin immediately.

\subsection{Groundwater Contamination}

Our groundwater resources are contaminating day by day due to various factors. The problems of groundwater quality could be classified into: problems of natural quality; deterioration in quality due to anthropogenic factors; and pollution by external contaminants. Groundwater resources in vast tracts of India are contaminated with fluoride, arsenic, salinity and heavy metals.

\subsubsection{Fluoride}

Fluoride problems exist in 225 districts of 19 states in the country with Rajasthan (30 districts) being the most severely 


\section{International Journal of Science and Research (IJSR) \\ ISSN (Online): 2319-7064}

Index Copernicus Value (2015): 78.96 | Impact Factor (2015): 6.391

affected. High concentration of fluoride in drinking water causes fluorosis resulting in weak bones, weak teeth, and anaemia.

\subsubsection{Arsenic}

In West Bengal, 79 blocks in 8 districts have Arsenic beyond the permissible limit of $0.05 \mathrm{mg} / \mathrm{l}$. Apart from West Bengal, arsenic contamination in ground water has been found in the states of Bihar (15 districts), Chhatisgarh (1 district), Uttar Pradesh (9 districts) and Assam (1 district). An area of around $75000 \mathrm{~m}^{2}$ in the alluvial deltaic sediments of the Ganga-Meghan-Brahmaputra river system is thought to be affected by high arsenic concentrations in the groundwater, putting several millions of people at potential risk.

\subsubsection{TDS \& Salinity}

Progressive decline in groundwater quality in terms of high TDS and salinity is encountered in North Gujarat with increase in pumping depths. In some areas of Rajasthan and Gujarat, ground water salinity is so high that the well water is directly used for salt manufacturing by solar evaporation.

\subsubsection{Iron}

High concentration of Iron $(>1.0 \mathrm{mg} / \mathrm{l})$ in ground water has been observed in more than 1.1 lakh habitations in the country. Ground water contaminated by iron has been reported from Andhra Pradesh, Assam, Bihar, Chhattisgarh, Goa, Gujarat, Haryana, J\&K, Jharkhand, Karnataka, Kerala, Madhya Pradesh, Maharashtra, Manipur, Meghalaya, Orissa, Punjab, Rajasthan, Tamil Nadu, Tripura, Uttar Pradesh, West Bengal and UT of Andaman \& Nicobar.

\subsubsection{Heavy Metals}

Presence of heavy metals in groundwater is found in 40 districts from 13 states: Andhra Pradesh, Assam, Bihar, Haryana, Himachal Pradesh, Karnataka, Madhya Pradesh, Orissa, Punjab, Rajasthan, Tamil Nadu, Uttar Pradesh, West Bengal, and 5 blocks of Delhi. In many situations, the status of groundwater quality is not known to the communities, particularly in the case of nitrate, fluoride and arsenic pollution. By the time communities are aware of the impending health hazard, they have long been exposed to the contaminated water.

\subsection{Groundwater Depletion \& Contamination}

The over-development of groundwater is threatening its supply in terms of depletion and deterioration of quality. India is the world's largest groundwater user, where during 2010 approximately $223 \mathrm{~km}^{3}$ of groundwater was pumped for irrigation; groundwater covers there $64 \%$ of the total irrigation consumptive water use. Groundwater covers a significant portion of the water demand for industries that are not connected to public water supplies and it is $27 \%$. Falling groundwater levels are observed in many arid and semi-arid regions of India, including parts of Gujarat, Rajasthan, Punjab, Tamil Nadu and Karnataka. The water levels are falling throughout Punjab at a rate of $0.30 \mathrm{~m}$ per annum. A sharp fall in water level would have serious implications for the investment required for pumping groundwater and also for the efficiency of its abstraction. In certain cases, excessive withdrawal of groundwater from coastal aquifers resulting in hydrostatic imbalance between sea water and fresh water causes intrusion of sea water.Out of 5842 numbers of assessment administrative units (Blocks/Taluks/Mandals/Watershed), 802 units are 'OverExploited', 169 units are 'Critical', 523 units are 'SemiCritical', 4277 units are 'Safe' and 71 units are 'Saline'.

Fig.1 showing Depth to Water Level Map indicates that in Sub-Himalayan area, north of river Ganges, Assam, Bihar, Chhattisgarh, Maharashtra, Jharkhand, Madhya Pradesh, Orissa, Bihar, Gujarat, Tripura and Coastal Tamil Nadu generally the depth to water level varies from 2-5meter below ground level (mbgl). Shallow water level less than 2 mbgl have also been observed as isolated patches in Maharashtra, Andhra Pradesh, Assam, Northern Uttar Pradesh, Madhya Pradesh, Gujarat and Orissa. In major parts of north-western States, depth to water level generally ranges from 10-40 mbgl. In the western parts of the Country, deeper water level is recorded in the depth range of $20-40 \mathrm{mbgl}$ and more than $40 \mathrm{mbgl}$. In some parts of Delhi and Rajasthan, water level of more than $40 \mathrm{mbgl}$ is recorded. Along the eastern and western coast, water level is generally less than $10 \mathrm{mbgl}$. Central part of the State of West Bengal recorded water level in the range of 5-10 mbgl and also 10-20 mbgl. In Central India, water level generally varies between less than $2 \mathrm{mbgl}$ to $5 \mathrm{mbgl}$, except in isolated pockets where water level less than $10 \mathrm{mbgl}$ has been observed. The peninsular part of Country, generally, recorded a water level in the range of 5 to $20 \mathrm{mbgl}$ depth range. 


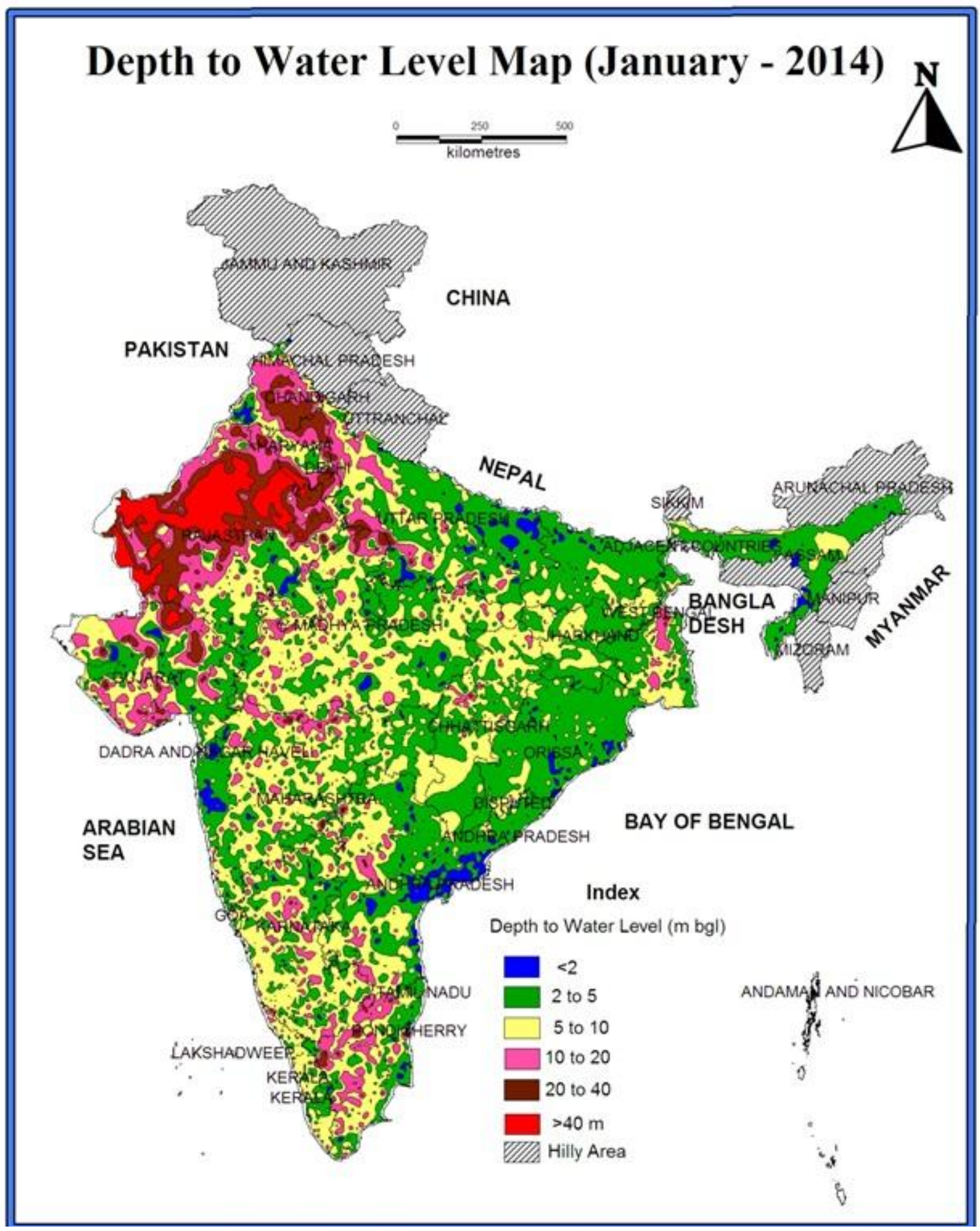

Source: Ministry of Water Resources

Figure 1: Depth to Water Level

\subsection{Water Pollution}

Water pollution is a serious problem in India as almost $70 \%$ of its surface water resources and a growing percentage of its groundwater reserves are contaminated by biological, toxic, organic and inorganic pollutants. In many cases, these sources have been rendered unsafe for human consumption as well as for other activities. A striking example of water pollution caused by the disposal of municipal sewage and drainage water has occurred in Delhi in 1956. The Najafgarh drain of Delhi bringing huge amounts of sewage and drainage water, used to discharge directly into Yamuna River just a few metres from the intake well for the main water works of the Delhi city. It polluted the drinking water supply, causing an outbreak of jaundice on a large scale, and thus affecting the health of numerous citizens.

Household borne effluents contribute a substantial proportion of water pollution in India. Untreated effluents from households pollute surface and groundwater sources. The use of polluted water downstream by human beings for their daily requirement would mean taking unsafe 


\section{International Journal of Science and Research (IJSR) \\ ISSN (Online): 2319-7064}

Index Copernicus Value (2015): 78.96 | Impact Factor (2015): 6.391

and unwholesome water which may cause the sporadic outbreak of waterborne diseases. Such situation may particularly arise in the case of unsewered small towns and cities situated close to the flowing rivers.

Though India has defined wastewater discharge standards for the domestic and industrial sectors, there are no discharge standards for the pollution emanating from agriculture. Agricultural run-off affect groundwater and surface water sources as they contain pesticide and fertilizer residues. Fertilizers have an adverse impact on water resources. Indeed, by increasing the nutritional content of water courses, fertilizers allow organisms to proliferate.

\subsection{Inadequate Wastewater Treatment Capacity}

In India, municipalities have the treatment capacity for about $30 \%$ of the wastewater generated in urban areas. This indicates a gloomy picture of sewage treatment, which is the main source of pollution of rivers and lakes. In 2008, cities which have a population of more than one lakh, treat about $32 \%$ of the wastewater generated. Note that out of the total effluent treatment capacity of 11554 MLD in the country, about $70 \%$ (8040 MLD) has been created in 35 metropolitan cities. Metropolitan cities treat about $52 \%$ of their wastewater. Delhi and Mumbai account for about $69 \%$ of the treatment capacity of metropolitan cities. This indicates that smaller towns and cities have very little wastewater treatment capacity.

\section{Management Strategies}

The key challenges to better management of water resources in India are uneven geographic distribution of surface water resources, overuse of ground water and contamination, drainage andsalinization and water quality problems due to treated, partially treated and untreated wastewater from urban settlements, industrial establishments and runoff from irrigation sector besides poor management of municipal solid waste and animal dung in rural areas.

The degree to which a water system fulfills its public health functions directly varies with the efficiency and effectiveness of its management. The basis of good management lies in proper maintenance of municipal accounts and records. Generally there are two types of records which include statistical and financial. Statistical records deal with details with regard to operation of water system i.e., water received through pumping and/or by gravity and water sold, new water connections made and laying of new lines. As for the financial record, it relates to handling of money and investment. Proper maintenance and availability of record is must for smooth functioning of an organization dealing with water system.

\subsection{Pollution Control Measures}

Conservation of the quality of fresh water sources by effective pollution control measures is an important area of the water supply system today.

\subsubsection{Public Consciousness}

It is necessary to create awareness about the conservation of water and stopping wastage through various methods like pamphlets urging to 'Be a leak seaker', 'Use all water you need, but use it wisely and not wastefully,' through public service announcements on radio, television and internet. Atmosphere can be created by which waste of water can be looked upon as a criminal act against the society as a whole.

\subsubsection{Industrial Cooperation}

It envisages adequate treatment of all such industrial wastes which are of toxic nature before being discharged into water courses. Since complete industrial wastewater treatment may in certain cases be expensive, industries should be given some incentive in the form of tax reduction so as to encourage them to undertake the treatment of wastewater before its disposal. On the other hand, industries causing pollution due to their production processes and making pollutant products should be subjected to pollution tax and heavy penalties.

\subsubsection{Legislative Control}

The legislative control is necessary to counter effectively all possible violations of pollution control practices. With the enactment of the Water (Prevention and Control of Pollution) Act 1974, amended in 1988 most of the states in our country have established Water Pollution Control Boards. This has resulted in setting up of wastewater treatment plants in number of industries in order to bring down the pollution level of the wastewater within the acceptable limits. In 2001, the Ministry of Environment and Forests, constituted the Water Quality Assessment Authority under the Environment (Protection) Act, 1986 with a view to monitor and take appropriate action for protecting the quality of National Water Resources.

\subsection{Reuse of Water}

For ever growing demand of water supply, the use of sewage and waste water is contemplated for non-domestic purposes like flushing, gardening, cooling, firefighting and other industrial uses, after giving necessary treatment. The connections to residential shall not be allowed from this source to avoid cross connection with drinking water supply system. There are many examples where waste waters have been used in full scale plants to supply water for industrial as well as municipal use. The use of Bombay municipal sewage by Union Carbide to provide process water is well known. 45 industries in Bombay covering mainly the textile agencies and a few chemical, pharmaceutical, engineering and other industries have adopted reuse of their process water in some form or the other; 5 tall buildings and 1 large industry in Bombay treat sewage in order to make it fit for re-use of cooling waters.

\subsection{Artificial Recharge \& Rainwater Harvesting}

In order to augment the depleting ground water resources, it is essential that the surplus monsoon runoff that flows into the sea, is conserved and recharged to augment ground water resources. Ground water storage that could be feasible has been estimated as 214 billion cubic meters (BCM) of which $160 \mathrm{BCM}$ is considered retrievable. Central Ground Water 


\section{International Journal of Science and Research (IJSR) \\ ISSN (Online): 2319-7064 \\ Index Copernicus Value (2015): 78.96 | Impact Factor (2015): 6.391}

Board has prepared a conceptual plan for artificial recharge to ground water for the country. Out of total geographical area of $3,28,7263 \mathrm{~km}^{2}$ of the country, an area of 4,48,760 $\mathrm{km}^{2}$ has been identified suitable for artificial recharge. The total quantity of surplus monsoon runoff to be recharged works out as $36.4 \mathrm{BCM}$.

During the Ninth Five Year Plan, a Central Sector Scheme on "Studies on Recharge of Ground Water" was undertaken, under which 165 recharge projects were implemented in 27 States/UTs. During the Tenth Five Year Plan, demonstrative studies on Artificial Recharge to Ground Water and Rain Water Harvesting have been taken up during 2006-07 by CGWB in 8 districts in Andhra Pradesh, Madhya Pradesh, Karnataka and Tamil Nadu at a total cost of Rs. 5.95 Crores.

\subsection{National Water Quality Monitoring Programme}

The CPCB in collaboration with concerned SPCBs/PCCs established a nationwide network of water quality

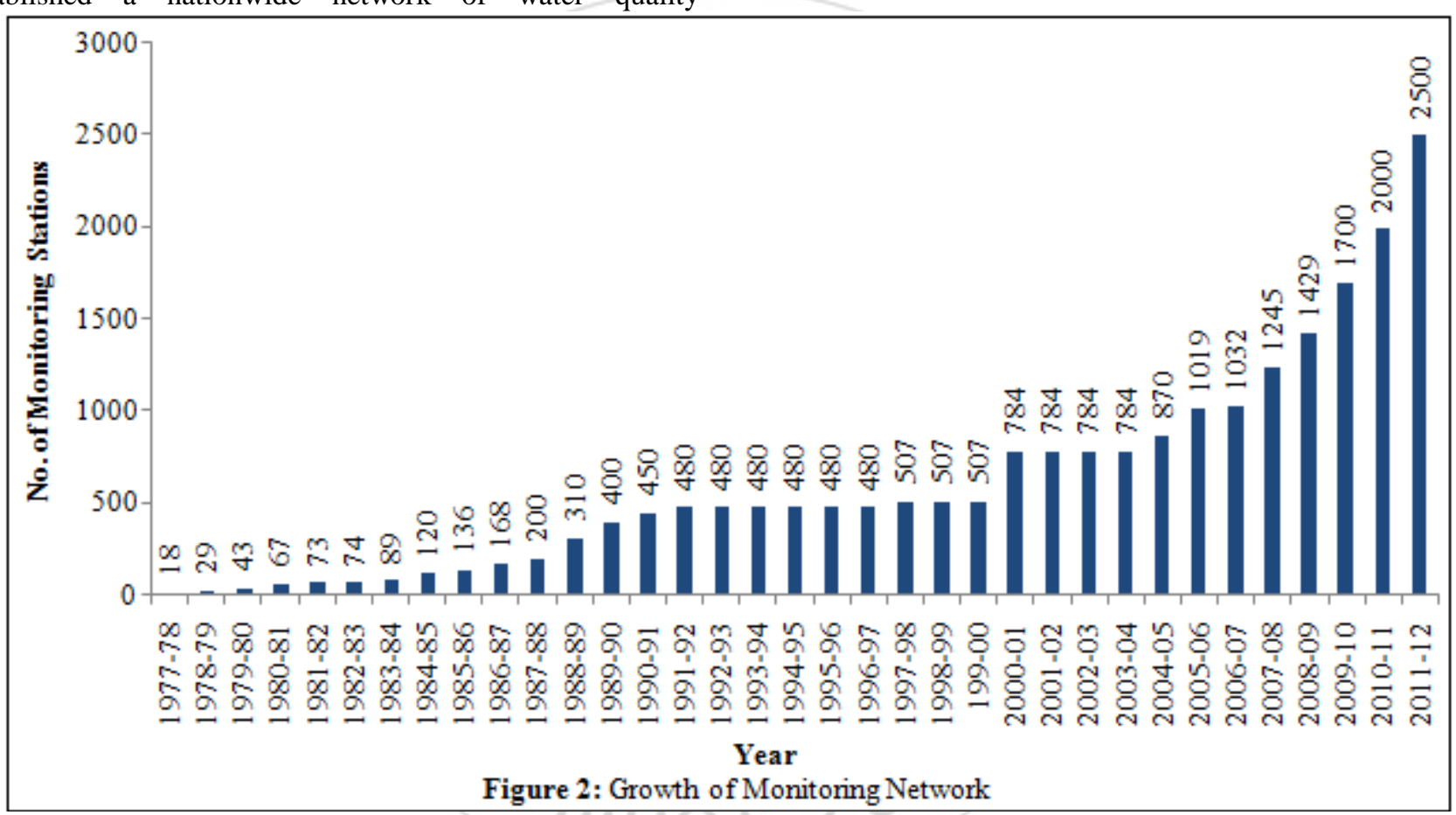

Source: CPCB

Figure 2: Growth of Monitoring Network

\section{Conclusion}

The availability and the quality of the fresh water resources is the most pressing of the many environmental challenges on the national horizon in India. The stress on water resources is from multiple sources and the impacts can take diverse forms. Even today when our country is not yet fully industrialised the pollution of rivers due to dumping of sewage and other wastes, especially near the towns and cities is indeed enormous. If the process is allowed to continue like this, a day will definitely come when we will not be able to find any clear water anywhere in the country. There is thus a pressing need for conserving the precious fresh water sources if water supply needs of growing population are to be met satisfactorily. Water is required not only in sufficient quantity, but of potable quality to live a healthy life. It should be made compulsory to all the private monitoring comprising 2500 stations in 28 States and 6 Union Territories. The monitoring is done on monthly or quarterly basis in surface waters and on half yearly basis in case of ground water. The monitoring network covers 445 Rivers, 154 Lakes, 12 Tanks, 78 Ponds, 41 Creeks/Seawater, 25 Canals, 45 Drains, 10 Water Treatment Plant (Raw Water) and 807 Wells. The year wise growth of monitoring network is depicted in Fig. 2.

There is an urgent need to increase the number of monitoring stations from their current number, which translate as one station per $1,935 \mathrm{~km}^{2}$ to levels found in developed nations for effective monitoring. It is observed that $32 \%$ of the stations have frequency of monitoring on a monthly basis, $28.82 \%$ on a half-yearly basis, and $38.64 \%$ on a quarterly basis. This indicates the need for not only increasing the number of monitoring stations but also the frequency of monitoring.

\section{Volume 6 Issue 1, January 2017




\section{International Journal of Science and Research (IJSR) \\ ISSN (Online): 2319-7064}

Index Copernicus Value (2015): 78.96 | Impact Factor (2015): 6.391

[5] Margat, Jean and Jac Gun (2013), “Groundwater around the World: A Geographic Synopsis”, CRC Press, London.

[6] Michael, A.M., S.D. Khepar and S.K. Sondhi (2008), "Water Wells and Pumps", Tata McGraw-Hill, New Delhi.

[7] Ministry of Water Resources, River Development \& Ganga Rejuvenation,

http://www.mowr.gov.in/forms/list.aspx?lid=297

http://www.mowr.gov.in/forms/list.aspx?lid=301\&Id=4 http://www.mowr.gov.in/forms/list.aspx?lid=304\&Id=4 http://www.mowr.gov.in/forms/list.aspx?lid=306\&Id=4

[8] Modi, P.N. (2001), "Sewage Treatment and Disposal and Wastewater Engineering”, Environmental Engineering Vol. II, Standard Book House, Delhi.

[9] Murty, M.N. and Surender Kumar (2011), "Water Pollution in India: An Economic Appraisal”, India Infrastructure Report.

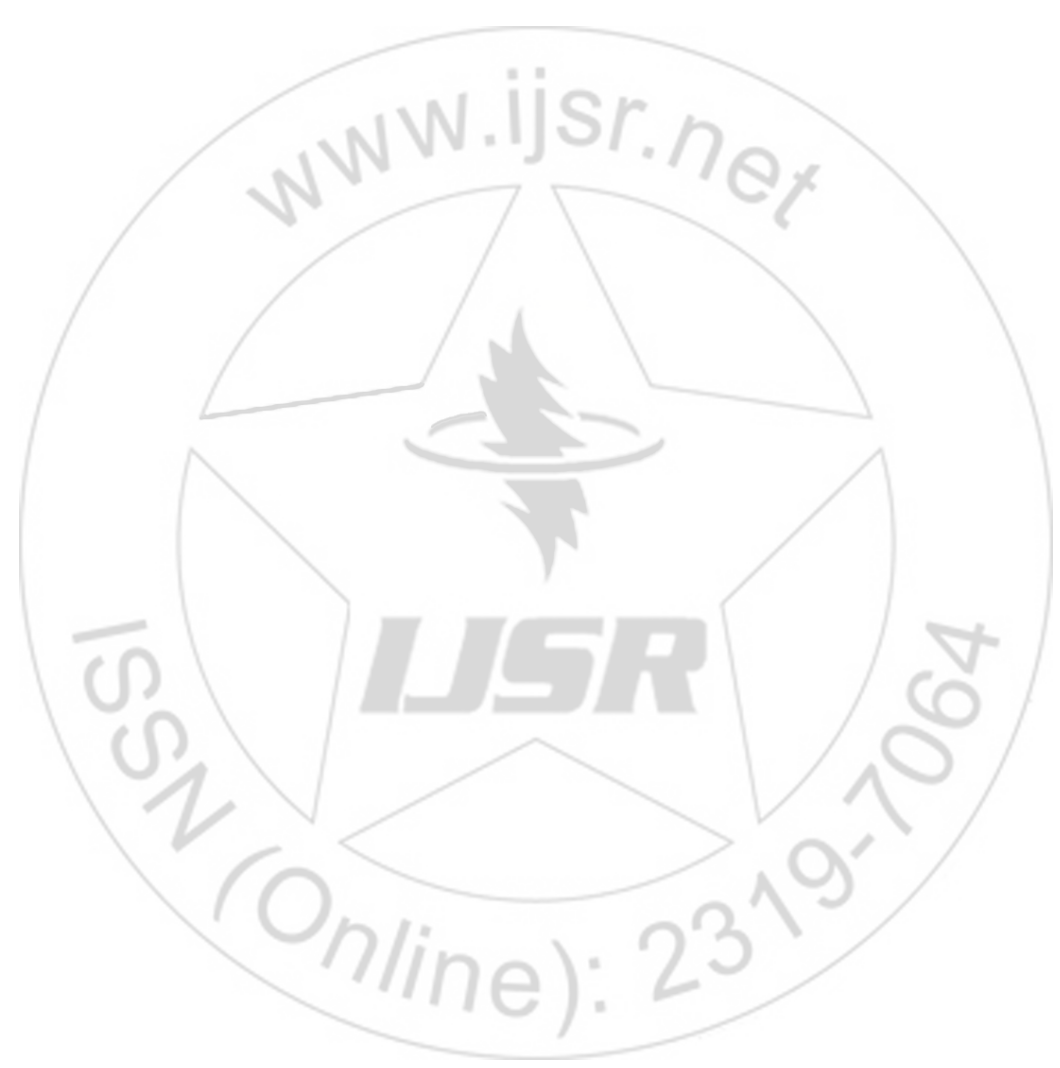

